\title{
PROFESSIONAL STRESS AND HEALTH AMONG CRITICAL CARE NURSES IN SERBIA
}

\author{
Dragana MILUTINOVIĆ ${ }^{1}$, Boris GOLUBOVIĆ ${ }^{2,3}$, Nina BRKIĆ ${ }^{4}$, and Bela PROKES $\check{S}^{5,6}$ \\ University of Novi Sad, Faculty of Medicine, Department of Nursing ${ }^{l}$; University of Novi Sad, Clinical Center of \\ Vojvodina, Clinic of Psychiatry²; University of Novi Sad, Faculty of Medicine, Department of Psychiatry and Medical \\ Psychology3; University of Novi Sad, Faculty of Medicine, Department of Special Rehabilitation and Education ${ }^{4}$; The \\ Institute for the Health Protection of Workers Novi Sad'; University of Novi Sad, Faculty of Medicine, Department of \\ Occupational Medicine 6 , Novi Sad, Serbia
}

Received in July 2011

CrossChecked in August 2011

Accepted in April 2012

\begin{abstract}
The aim of this study was to identify and analyse professional stressors, evaluate the level of stress in nurses in Intensive Care Units (ICU), and assess the correlation between the perception of stress and psychological and somatic symptoms or diseases shown by nurses. The research, designed as a crosssectional study, was carried out in the Intensive Care Units (ICU), in health centres in Serbia. The sample population encompassed 1000 nurses. Expanded Nursing Stress Scale (ENSS) was used as the research instrument. ENSS revealed a valid metric characteristic within our sample population. Nurses from ICUs rated situations involving physical and psychological working environments as the most stressful ones, whereas situations related to social working environment were described as less stressful; however, the differences in the perception of stressfulness of these environments were minor. Socio-demographic determinants of the participants (age, marital status and education level) significantly affected the perception of stress at work. Significant differences in the perception of stressfulness of particular stress factors were observed among nurses with respect to psychological and somatic symptoms (such as headache, insomnia, fatigue, despair, lower back pain, mood swings etc.) and certain diseases (such as hypertension, myocardial infarction, stroke, diabetes mellitus etc). In view of permanent escalation of professional stressors, creating a supportive working environment is essential for positive health outcomes, prevention of job-related diseases and better protection of already ill nurses.
\end{abstract}

KEY WORDS: professional stressors, psychological and somatic symptoms, questionnaires, workplace

Stress is one of the most severe occupational risks in the European Union. After back pain and musculoskeletal diseases, it is the second most prevalent work-related health problem (1). According to WHO Expert Committee (1985), work-related diseases are defined as a "wide spectrum of diseases of multifactorial aetiology, which are partly associated with profession or working conditions" (2). In addition to well-known physical, chemical and ergonomic factors, indirect mechanisms such as psychosocial factors and chronic professional stress may play an important role in the development of such diseases (2).

Occupational stress occurs when demands of the working environment overpower the capacities of workers to cope with them. It can affect all categories of workers and all professional areas $(1,3)$. Professional stress can also be defined as a "pattern of emotional, cognitive, behavioural and physiological reactions to adverse and harmful aspects of work content, work organisation and the working environment" $(4,5)$. 
Recent studies suggest that $50 \%$ to $60 \%$ of all lost working days are related to professional stress $(1$, $6)$. According to conclusions of the majority of available research, a higher rate of professional stress is established among middle-aged population, widowed, divorced or separated individuals and among professional groups such as nurses, teachers, and managers (7-9).

\section{Professional stress in nurses}

There seems to be a general agreement that workrelated stress: decreases the quality of nursing and nursing care, negatively affects job satisfaction (10), increases psychiatric morbidity (high rate of anxiety and depression $)(11,12)$, and triggers the development of some physical disorders, particularly cardiovascular (13) and locomotor diseases $(14,15)$.

Research on professional stress in nurses focuses mainly on nurses employed in hospital settings. Early investigations by Gray-Toft and Anderson $(16,17)$ identified seven major sources of stress among nurses: facing death and dying, conflicts with physicians, inadequate preparation to meet emotional needs of patients and their families, lack of support, conflicts with other nurses and supervisors, labour standards and uncertainty concerning treatment. The results of their studies correspond to the results of later research, which then added several other stress factors to the list: fear of making mistakes, limitations on organisational level, work in shifts and disproportion between work and reward (8, 18-23).

Some authors investigated if the sources of stress usually reported in literature were identical or similar for all nurses employed in hospitals, or they differed across hospital departments and nursing specialities (24-26). Results of these studies revealed significantly higher values of stress factors in relation to the items such as conflicts with physicians, problems with supervisors, and uncertainty concerning treatment in nurses in Intensive Care Units (ICU) compared to other departments. Stress situations such as performing procedures that are painful for the patient and fear of making mistakes were also recurrent in critical care nurses (24-26).

ICU nurses are expected to have superior professional knowledge and skills, be familiar with modern technical equipment and dedicated to the patient (27). Requirements for working in ICUs differ from one country to another. Contrary to most European countries, particular education and training for this type of nursing is not available in Serbia. Nurses acquire knowledge and training through experience rather than by advanced and specialised ICU education.

According to the data of the Serbian Chamber of Nurses and Medical Technicians, there are $91.3 \%$ of secondary school nurses and only $9.7 \%$ of nurses with high professional qualifications (baccalaureate). However, the curricula and syllabi of the secondary four-year nursing schools (which students attend after eight-year primary school) lack training on intensive care methods and patient-oriented health care systems. In such work environment, professional stressors are expected to appear, leading to a number of different diseases.

\section{The aim of the study}

The aim of this study was to identify and analyse professional stressors, evaluate the level of stress in nurses in ICUs, and assess the correlation between the perception of stress and psychological and somatic symptoms or diseases shown by nurses.

\section{METHODS}

\section{Samples and settings}

The research was carried out in the ICUs in twentytwo health centres in Serbia, which provide secondary and tertiary level health services. The ICUs were centralised (general) and specialised (surgery, internal medicine and paediatrics) depending on the type of healthcare institution. The study was designed as a cross-sectional study, using an opinion poll method. The randomised sample population encompassed 1000 nurses.

A working group made of nurses from the Serbian Association of Nurses and Technicians of Intensive Care, Anaesthesia and Reanimation distributed the questionnaires and collected the data for the population. A total of 1150 questionnaires were sent out and 1000 of them were considered for final processing; the remaining questionnaires were either not returned or returned incomplete, lacking majority of required data. In the questionnaires with only a few missing items, responses were replaced by the average value for a given item obtained in this sample. Therefore, the overall response rate for participation in the study was $86.9 \%$.

\section{Instruments}

To assess and analyse professional stressors, we applied the Expanded Nursing Stress Scale (ENSS) 
(28). The ENSS is an expanded and updated version of the classic Nursing Stress Scale (NSS) developed by Gray-Toft \& Anderson (1981). The NSS scale was the first instrument to target nursing stress rather than general job stress. The original 34 items of NSS measured the frequency and major sources of stress in patient care situations (16). Major changes in health care delivery and work environment of nurses stimulated French et al. (2000) to identify stressful situations not reflected in the NSS scale and develop an expanded version useful for various work settings. The researchers then tested the 59 item ENSS on a larger sample $(\mathrm{N}=2.280)$ after which two items were removed from the instrument. The final ENSS contained 57 items in nine subscales related to: physical, psychological, and social working environments. The 57 items were arranged in a 5 point Likert response scale. The offered response options were: 'does not apply' (0), 'never stressful' (1), 'occasionally stressful' (2), 'frequently stressful' (3) and 'extremely stressful' (4). The response (0) indicated that the respondent had never faced the situation described by the item, and therefore the final calculation of total score for this respondent was $(0)$. Calculation of the average value was performed excluding zero values. Internal consistency reliability was assessed using Cronbach's coefficient alpha. The 57 -item ENSS showed improved reliability $(\alpha=0.96)$ over the original NSS $(\alpha=0.89)$. Individual subscale reliability ranged from $\alpha=0.88$ (problems with supervisors) to $\alpha=0.65$ (discrimination) (28).

The questionnaire was in this case cross-culturally adapted to meet the criteria of the research (29). The instrument was translated into Serbian, and back translation (from Serbian to English) was provided as a validity check. One author (DM) resolved language discrepancies.

Besides the ENSS scale, we applied a supplementary questionnaire to obtain socio-demographic data (gender, age, marital status, material status and housing problems), data related to workplace (service length, night shift work, duties, temporary assignment to other duties, and continuous professional education possibilities) and data on presence/absence of psychological and somatic symptoms and diseases in the previous six months. In addition to these, the questionnaire included the data on smoking and excessive coffee ingestion habits because these were considered to be a behavioural disorder caused by chronic professional stress and a risk factor for a variety of multifactorial diseases including workrelated diseases.

\section{General characteristics of sample population}

Our sample population included 951 women $(95.1 \%)$ and 49 men $(4.9 \%)$. The average age of participants was $(33.2 \pm 8.5)$ years. Five hundred and sixty-five nurses $(56.5 \%)$ were married, 576 had one or more children (57.6\%), and 557 nurses $(55.7 \%)$ described the material status of their families as "average".

Most participants completed secondary education (842; 84.2\%), while 158 (15.8\%) achieved higherlevel education. As far as their workplace and duties were concerned, most nurses $(747 ; 74.7 \%)$ said they worked in shifts.

\section{Ethical consideration}

The study was examined and approved by the Research Ethics Committee of the Faculty of Medicine where the researchers currently work, as well as by hospitals' administrators. Nurses were contacted and invited by their nurse managers to participate in the current study but the nature of their participation was voluntary. Each potential subject was informed about the nature of the study in an introductory letter. Nurses' anonymity and the confidentiality of their information were guaranteed. No code numbers or any other identifying marks were printed on the questionnaires. Code numbers were placed on the questionnaires once these were returned.

\section{Statistical analysis}

The Statistical Package for Social Sciences (SPSS, Version 14) was used to generate descriptive and inferential statistics. Minimum significance level was set to 0.05 . Means, standard deviations and frequencies were reported for the sample's variables. Each group of stress factors was analysed in relation to the workplace and socio-demographic determinants using the ANOVA test. The respondents were stratified into four groups according to age (20 to 29,30 to 39,40 to 49,50 and over), education level (secondary, higher education), marital status (married, divorced, widowed, single), and smoking status (smoker, nonsmoker, ex-smoker). The independent samples $t$-test and nonparametric Mann-Whitney U-test test were applied to common habits, such as excessive coffee consumption (up to 3 or more than 3 cups per day), and health status determinants. The independent samples $t$-test was used to determine differences in the perception of diverse stressogenic situations between respondents with certain symptoms of disease 
and those without the symptoms. A small number of respondents reported history of diabetes, angina, malignant diseases, stroke, and infarction, thus the analysis of stress perception between such respondents and those without mentioned diseases was performed using the nonparametric Mann-Whitney U-test. This helped us to define particular factors, i.e. stress situations differently perceived by nurses, depending on the existence or absence of some psychological and somatic symptoms or diseases. Cronbach's $\alpha$ (alpha) and inter-item correlation was used as a measure of internal consistency and reliability. Confirmatory factor analysis (CFA) was used to determine if the number of factors conformed to what was expected on the basis of the pre-established hypothesis.

\section{RESULTS}

ENSS revealed a valid metric characteristic within our sample population. Cronbach alpha for the entire scale was $(\alpha=0.94)$, and $>0.70$ for all subscales except the categories conflicts with physicians $(\alpha=0.65)$ and inadequate preparation $(\alpha=0.59)$. The average interitem correlation was 0.22 , whereas item-total correlation ranged between 0.20 and 0.60 .

The theoretical background of factorial structure of the questionnaire was confirmed by CFA. The initial factorial analysis, which included 57 items, revealed nine factors that highly corresponded to the nine subscales of ENSS. These nine factors accounted for $52 \%$ of nursing stress variance. The second-order factor analysis discerned three factors: physical, psychological, and social working environments. Physical working environment was described by the subscale workload, while psychological working environment was described by the following subscales: death and dying, inadequate preparation, and uncertainty concerning treatment. The third factor social working environment - was described by the following subscales: conflicts with physicians, problems with peers, problems with supervisors, patients and their families, and discrimination.

\section{Stress situation analysis}

A descriptive analysis of arithmetic means with respect to three dimensions of work environment and nine subscales of the questionnaire and their comparison (Table 1) lead us to conclude that critical care nurses rated situations related to physical and psychological working environments as the most stressful ones, whereas situations related to social working environment were seen as less stressful. However, differences in the perception of a stressogenic level of these working environments were small. The analysis of stress situation groups revealed that nurses rated the death and dying group situations as the most stressful, $\mathrm{M}=2.87 ; \mathrm{SD}=0.92$, whereas the problems with peers group situations were rated $\mathrm{M}=2.09 ; \mathrm{SD}=0.93$ and were considered the least stressful (Table 1).

The analysis of all 57 potentially stressful situations in ICUs revealed that working in conditions that might endanger their health and safety was the most stressful experience for nurses ( $\mathrm{M}=3.17$; $\mathrm{SD}=0.91)$, as was the death of a patient with whom they developed a close relationship $(\mathrm{M}=3.13 ; \mathrm{SD}=1.02)$.

Separate ANOVA analysis showed significant differences in the perception of each of nine stressful situations in relation to age, marital status, and education level. The results revealed that married nurses experienced a higher level of stress at work in the situations of the death and dying $(\mathrm{p}=0.01)$ and workload (0.03) subscales compared to divorced or single nurses. With respect to age, certain differences were observed as regards the problems with colleagues $(\mathrm{p}=0.00)$ and problems with supervisors $(\mathrm{p}=0.01)$ subscales, which showed that nurses in the age category 30 to 39 years experienced a higher stress level compared to their younger or older co-workers. As far as education level is concerned, considerable differences appeared in the domain of discrimination $(\mathrm{p}=0.02)$ and problems with supervisors $(\mathrm{p}=0.03)$. These situations were found to be more stressful by the nurses with secondary education level than by those with a higher-level education.

\section{Analysis of nurses' common habits and health statuses}

Average coffee consumption among nurses participating in the poll was 2.8 cups $(\mathrm{SD}=1.7)$. One third of nurses, $322(32.2 \%)$, declared themselves as non-smokers, $452(45.2 \%)$ as smokers, and 226 $(22.6 \%)$ as ex-smokers. However, further analysis did not reveal any significant differences in the perception of stressfulness of different situations at the workplace between nurses with these common habits and those without them.

Less than half of nurses reported headache and lower back pain, 424 (42.4\%) and 406 (40.6\%), respectively. Mood swings $(280 ; 28.0 \%)$ and fatigue 
Table 1 Mean values for intensity of all stress situation categories

\begin{tabular}{lcccc}
\hline Subscales and number of items & Mean & SD & Min. & Max. \\
\hline DD - Death and dying - 7 items & 2.87 & 0.92 & 0 & 28 \\
\hline CP - Conflict with physicians - 5 items & 2.52 & 0.94 & 0 & 20 \\
\hline IP - Inadequate preparation - 4 items & 2.19 & 0.84 & 0 & 16 \\
\hline PP - Problems with peers - 6 items & 2.09 & 0.93 & 0 & 24 \\
\hline PS - Problems with supervisors - 7 items & 2.56 & 0.99 & 0 & 28 \\
\hline WL - Workload - 9 items & 2.55 & 1.01 & 0 & 36 \\
\hline UT - Uncertainty concerning treatment - 8 items & 2.57 & 0.93 & 0 & 32 \\
\hline PF - Patients and their families - 8 items & 2.71 & 1.02 & 0 & 32 \\
\hline D - Discrimination - 3 items & 2.58 & 1.14 & 0 & 12 \\
\hline $\begin{array}{l}\text { Dimensions of the work environment and the number } \\
\text { of subscales contained }\end{array}$ & Mean & SD & Min. & Max. \\
\hline Physical - 1-subscale & 2.55 & 1.01 & 0 & 36 \\
\hline Psychological - 3 subscales & 2.54 & 0.89 & 0 & 76 \\
\hline Social - 5 subscales & 2.49 & 1.04 & 0 & 116 \\
\hline Physal (WL), psychological (DD;
\end{tabular}

Physical (WL), psychological (DD; IP; UT) and social working environment (CP; PP;

PS; PF; D).

$(271 ; 27.1 \%)$ were observed in one-quarter of polled nurses.

Table 2 shows the differences in the perception of stressfulness of different situations in participants with and without certain symptoms. Significant differences were observed among nurses with respect to psychological and somatic symptoms, such as headache, insomnia, fatigue, despair, lower back pain, frequent mood swings, excessive sweating, and shortness of breath, chest pain and palpitations. Interestingly, insomnia, fatigue, and headache are symptoms related to the perception of the most stressful situations given in the questionnaire. However, the participants who felt anxiety and anger and those with appetite disturbances did not differ significantly with respect to the perception of stressfulness of any of the stress factors at work.

Nurses who had been experiencing lower back pain and headache for the past six months considered situations in the social working environment to be significantly more stressful (conflicts with physicians, problems with supervisors, problem with peers, and patients and their family members) than other situations compared to the nurses without these symptoms. Nurses suffering from insomnia, fatigue, and headache perceived situations in the domain of physical and psychological working environments (all subscales) and problems with supervisors subscale from the social working environment as significantly more stressful than other situations compared to the nurses without these symptoms.
Table 2 shows that the perception of certain stressogenic situations at work is closely related to certain symptoms and problems, while other types of stressful events are not related to any of the examined symptoms. The perception of discrimination at work and problems with patients and their families are not connected with any symptoms. Stressful situations in the realm of the conflicts with physicians, problems with supervisors, uncertainty of treatment, and workload subscales are connected with almost all symptoms, while stressful situations from other subscales are only connected with a few symptoms.

Table 3 shows the differences in the perception of stressfulness of nine situational factors between participants with and without diseases.

Out of the total number of investigated nurses, 84 $(8.4 \%)$ reported hypertension, 75 (7.5\%) peptic or duodenal ulcer disease, $52(5.2 \%)$ gallbladder inflammation or gallstones, $30(3.0 \%)$ chronic bronchitis / asthma, and $17(1.7 \%)$ diabetes.

It is important to emphasise that nurses who had at least one of the examined diseases perceived the events from the domains of death and dying, problems with supervisors and discrimination problems as highly stressful. Both, nurses with and without diseases, equally perceived stressogenic effects of the situations from the domains of workload, competence at work and problems with patients and their families. 
Table 2 Differences in the perception of stressfulness of different stress situations between participants with and without certain symptoms

\begin{tabular}{lcccccccccc}
\hline \multirow{2}{*}{ Symptoms } & $\mathbf{N}$ & $\mathbf{D D}$ & $\mathbf{C P}$ & $\mathbf{I P}$ & $\mathbf{P P}$ & $\mathbf{P S}$ & $\mathbf{W L}$ & $\mathbf{U T}$ & $\mathbf{P F}$ & $\mathbf{D}$ \\
\cline { 2 - 11 } & & $\mathbf{t}$ & $\mathbf{t}$ & $\mathbf{t}$ & $\mathbf{t}$ & $\mathbf{t}$ & $\mathbf{t}$ & $\mathbf{t}$ & $\mathbf{t}$ & $\mathbf{t}$ \\
\hline Despair & 36 & 1.41 & $3.05^{* *}$ & 1.63 & $2.57^{* *}$ & $2.06^{*}$ & 1.77 & $2.18^{*}$ & 0.89 & 0.76 \\
\hline Anxiety & 108 & 1.39 & 0.11 & 0.27 & 0.35 & 1.91 & 1.64 & 0.64 & 0.03 & 0.41 \\
\hline Mood swings & 280 & 1.32 & $2.22^{*}$ & 1.16 & 0.39 & $1.97^{*}$ & $3.35^{* *}$ & 1.67 & 1.87 & 0.34 \\
\hline Sweat & 73 & 0.78 & $2.76^{* *}$ & 0.34 & 1.67 & 1.28 & 1.35 & 0.66 & 0.03 & 0.21 \\
\hline Insomnia & 122 & $3.29^{* *}$ & $4.46^{* *}$ & $2.14^{*}$ & 1.22 & $4.24^{* *}$ & $3.67 * *$ & $2.95^{* *}$ & 1.89 & 0.12 \\
\hline Appetite changes & 127 & 0.28 & 0.49 & 0.05 & 1.30 & 0.26 & 1.34 & 1.13 & 0.66 & 0.70 \\
\hline Anger & 136 & 0.38 & 1.27 & 0.28 & 0.35 & 0.29 & 1.76 & 0.62 & 0.57 & 0.12 \\
\hline Fatigue & 271 & $2.41^{* *}$ & $3.19^{* *}$ & 0.33 & 1.75 & $3.02^{* *}$ & $2.61 * *$ & $3.87 * *$ & 0.55 & 0.41 \\
\hline Lower back pain & 406 & 1.19 & $2.64^{* *}$ & $2.30^{*}$ & 1.26 & $1.98^{*}$ & 1.95 & $2.02^{*}$ & 0.75 & 0.32 \\
\hline Palpitation & 218 & 2.55 & $2.05^{*}$ & 1.82 & 0.65 & 1.40 & $1.96^{*}$ & 1.61 & 0.25 & 0.82 \\
\hline Dyspnoea & 87 & 0.003 & 1.16 & 1.34 & 1.07 & 0.02 & $1.96^{*}$ & $2.06^{*}$ & 0.42 & 0.73 \\
\hline Chest pain & 87 & $2.89^{* *}$ & $2.22^{*}$ & $2.53^{* *}$ & 0.95 & 1.49 & 1.17 & 1.53 & 0.49 & 0.32 \\
\hline Headache & 424 & $3.02^{* *}$ & $2.32^{*}$ & 1.39 & $2.77 * *$ & $4.02^{* *}$ & $2.76^{* *}$ & $2.78^{* *}$ & $2.09^{*}$ & 1.14 \\
\hline
\end{tabular}

*Significance level $p<0.05$

$* *$ Significance level $p<0.01$

$D D$ - Death and dying; CP - Conflict with physicians ; IP - Inadequate preparation; PP - Problems with peers; PS - Problems with supervisors; WL - Workload; UT - Uncertainty concerning treatment; PF - Patient and his family; D - Discrimination; $N$ - number of respondents who reported symptoms

$t$ - $t$-test

Table 3 Differences in the perception of stressfulness of nine stress situations between participants with and without disease

\begin{tabular}{|c|c|c|c|c|c|c|c|c|c|c|}
\hline \multirow{2}{*}{ Disease } & \multirow{2}{*}{$\mathbf{N}$} & \multirow{2}{*}{$\begin{array}{c}\text { DD } \\
t\end{array}$} & \multirow{2}{*}{$\begin{array}{c}\mathrm{CP} \\
\mathrm{t}\end{array}$} & \multirow{2}{*}{$\begin{array}{c}\text { IP } \\
t \\
\end{array}$} & \multirow{2}{*}{$\begin{array}{c}\text { PP } \\
t\end{array}$} & \multirow{2}{*}{$\begin{array}{c}\text { PS } \\
\mathbf{t} \\
\end{array}$} & \multirow{2}{*}{$\frac{\mathrm{WL}}{\mathrm{t}}$} & \multirow{2}{*}{$\begin{array}{c}\mathrm{UT} \\
\mathrm{t}\end{array}$} & \multirow{2}{*}{$\begin{array}{c}\text { PF } \\
t\end{array}$} & \multirow{2}{*}{$\begin{array}{c}\text { D } \\
\mathbf{t}\end{array}$} \\
\hline & & & & & & & & & & \\
\hline $\begin{array}{l}\text { Gallbladder } \\
\text { inflammation or } \\
\text { gallstones (gallbladder } \\
\text { surgery) }\end{array}$ & 52 & 1.07 & $2.32 *$ & 1.64 & 1.31 & 0.27 & 1.36 & 0.63 & 1.92 & 0.83 \\
\hline $\begin{array}{l}\text { Stomach ulcer or } \\
\text { duodenal ulcer }\end{array}$ & 75 & 1.11 & 0.40 & 0.70 & 1.82 & 0.35 & 1.47 & 0.05 & 0.38 & 1.16 \\
\hline $\begin{array}{l}\text { Chronic bronchitis or } \\
\text { asthma }\end{array}$ & 30 & $2.07^{*}$ & 0.10 & 0.14 & 0.37 & 1.88 & 0.39 & 0.75 & 0.77 & $2.11 *$ \\
\hline Hypertension & 84 & 1.94 & $2.92 * *$ & $2.09 *$ & 1.80 & $2.08 *$ & 1.59 & 1.82 & 1.78 & 1.21 \\
\hline \multirow{2}{*}{ Disease } & \multirow{2}{*}{$\mathbf{N}$} & DD & $\mathbf{C P}$ & IP & $\mathbf{P P}$ & PS & WL & UT & PF & D \\
\hline & & $\mathbf{U}$ & $\mathbf{U}$ & $\mathbf{U}$ & $\mathbf{U}$ & $\mathbf{U}$ & $\mathbf{U}$ & $\mathbf{U}$ & $\mathbf{U}$ & $\mathbf{U}$ \\
\hline Malignant disease & 3 & $149 *$ & 856 & 761 & 258 & $105 *$ & 479 & 755 & 354 & $132 *$ \\
\hline Diabetes mellitus & 17 & $17189 *$ & 20818 & 19953 & 20000 & $16931 *$ & 20171 & 19073 & 18613 & $16901^{*}$ \\
\hline Stroke & 3 & $163^{*}$ & 352 & 287 & 374 & $142 *$ & 612 & 518 & 441 & $120 *$ \\
\hline Myocardial infarction & 3 & $147^{*}$ & 760 & 286 & $112 *$ & $108^{*}$ & 552 & 534 & 601 & $116^{*}$ \\
\hline Angina pectoris & 6 & 2722 & 2457 & 2955 & 2766 & 2521 & 2034 & 2040 & 2558 & 2769 \\
\hline \multicolumn{11}{|c|}{$\begin{array}{l}\text { *Significance level } p<0.05 \\
* * \text { Significance level } p<0.1 \\
D D \text { - Death and dying; } C P \text { - Conflict with physicians ; IP - Inadequate preparation; PP - Problems with peers; PS - Problems } \\
\text { with supervisors; WL - Workload; UT - Uncertainty concerning treatment; PF - Patient and his family; D - Discrimination; } \\
N \text { - number of respondents who reported symptoms }\end{array}$} \\
\hline
\end{tabular}




\section{DISCUSSION}

The effects of job-factors on the occurrence of professional diseases are well established, yet their role in the development and outbreak of work-related diseases is still unclear. Work-related diseases can be prevented, and recognizing and understanding all risk factors is of paramount importance. In that respect, this research aimed at analysing professional stress in ICU nurses as a potential risk factor for work-related diseases, and implementing appropriate preventive measures.

Nurses are exposed to various stress sources from physical, psychological and social working environments. Furthermore, socio-demographic determinants of the participants in our study (age, marital status and education level) proved to significantly influence stress perception at work. Nurses who are married experience higher stress level than single nurses. It has been suggested that such higher stress levels result from multiple and complex roles that these women have to perform: wife, mother, employee and housekeeper (30).

The most intense stressors for critical care nurses are related to their psychological working environment, such as death and dying, which corresponds to the results obtained by other authors, and distress related to this domain is reported to persist approximately a week after patients die $(16,20,31)$.

Furthermore, other significant stressors for nurses in ICUs are related to their physical working environment, i.e. workload (overtime work, shift work, inappropriate work/rest regimens, and pressure to have something done in a very short time).

A simple distribution analysis of items pertaining to the factor problems with supervisors and peers revealed that the lack of support from direct supervisors, difficulties in working with peers, and the impossibility of exchanging experiences and feelings with other staff are important professional stressors. Another significant work-related stressor is the problem with patients and their families: working with patients seems to cause excessive workload because nurses must provide psychological support and/or respond to the patient's' dissatisfaction or complaints.

The results of this study indicated a close connection between work-related stress factors and psychosomatic health. The most commonly reported psychological and somatic symptoms were: headache, lower back pain, fatigue, mood swings and insomnia.
These findings are similar to those of other researchers $(12,15,33-35)$.

Headache is one of the symptoms of professional stress and is usually associated with general fatigue and sleep disturbance (32). Our results are consistent with this implication. Stressful situations such as heavy workload, and problems with peers and superiors are correlated with high incidence of headache. It seems that these results are similar to the results of a research conducted in Taiwan, where worsening of the patient's condition, poor patientnurse relations, poor doctor-nurse relations and poor interpersonal relations among nurses, as well as insufficient medical knowledge were reported as possible causes of headache in nurses (32). High prevalence of headache could also be attributed to novel technologies, as complex technical equipment in ICUs requires rapid update of knowledge and skills, which along with constant time pressure leads to "techno-stress" (36). This type of mental strain leads to the sense of insecurity and confusion associated with fear of making mistakes, pronounced anxiety, and difficulties in relaxing after work (37).

Lower back pain is the second most reported somatic problem in nurses participating in this study. The high frequency of lower back pain can be explained not only by physical factors at work, but with psychosocial factors too. These results are similar to Yip's study (33), in which working in a team with poor relations was associated with an increased risk of lower back pain.

Significant differences in the perception of stressfulness were observed among nurses with respect to psychological and somatic symptoms and diseases, particularly those from the group of work-related diseases such as malignant diseases, diabetes mellitus, and cardiovascular diseases. This suggests that such perception is considerably associated with occurrence of certain symptoms and diseases in nurses. In spite of limited supporting evidence, psychosocial stress at workplace can be considered an independent predictor of type 2 diabetes, and chronically elevated cortisol levels during chronic psychosocial stress play a crucial role in explaining this correlation (37). The relationship of work-related stress and malignant diseases is the subject of an intensive ongoing investigation, thus work stress and shift work are considered new individual risk factors for cancer (38).

The results of this study strongly suggest introducing new strategies and measures into the working environment in ICUs to improve psychosocial and 
physical health of nurses. The first measure to undertake is to improve psychosocial work climate by providing more social and emotional support to nurses by their associates and supervisors. In view of permanent escalation of professional stressors, creating a supportive working environment is essential for positive health outcomes, prevention of job-related diseases and better protection of already ill nurses, which is in line with results and recommendations of other researchers (39).

Likewise, critical care nurses need to be trained through a stress-management program. This would help boost their confidence and develop abilities to communicate with doctors, chief nurses, and other nurses, which would improve overall teamwork. Managerial skills acquired this way could also reduce stress caused by bureaucratic and organisational tasks in the ward. Providing other forms of continuous professional training and acquiring techniques for handling new and modern equipment represent an important part of workplace safety. The implementation of these strategic measures is responsibility of the health facility management, team of experts implementing workplace safety, and nurses.

\section{Limitations of the study}

Although a large number of respondents participated in the study, it is not free from limitations. This study is fundamentally a cross-sectional study and shows the current status quo in regard to our test problem. In order to establish the cause-effect relations, it is necessary to conduct longitudinal studies.

\section{CONCLUSION}

It is widely accepted that nurses are exposed to various stress sources from physical, psychological and social working environments.

Our research underlined that:

- Socio-demographic determinants of participants (age, marital status and education level) significantly affect perception of stress at work.

- Stress situations related to psychological working environment, particularly facing suffering and dying, are significant professional stressors for critical care nurses in Serbia. This emphasises the need to learn to accept death as a part of everyday life rather than experience it as a clinical failure.
- There is a close connection between perception of stress at work and psychosomatic health of nurses.

\section{Acknowledgments}

The authors would like to thank The Association of Nurses - Technicians of Intensive Care, Anaesthesia and Reanimation of Serbia for organisational and financial support in collecting and analysing data.

\section{REFERENCES}

1. Cox T, Griffiths A, Cox S, Rial-González E. Research on Work-Related Stress. Luxemburg: European Agency for Safety and Health at Work; 2000.

2. Peruničić B. Bolesti u vezi s radom [Work-related diseases, in Serbian]. In: Vidaković A, editor. Medicina rada I. Beograd: KCS; Institut za medicinu rada i radiološku zaštitu "Dr Dragomir Karajović", Udruženje za medicinu rada Jugoslavije; 1997. p. 929-46.

3. Michi S. Causes and management of stress at work. Occup Environ Med 2002;59:67-72.

4. Diamantopoulou A. Europe under stress. In: Working on stress. Magazine of the European Agency for Safety and Health at Work 5 [displayed 8 February 2006]. Available at http://www.osha.europa.eu/en/publications/magazine/5

5. European Commission. Guidance of work-related stress. Spice of life or kiss of death? Luxembourg: Office for Official Publications of the European Communities, 2002 [displayed 11 March 2008]. Available at http://www.isma.org.uk/pdf/ publications/ke4502361_en.pdf

6. Verhaeghe R, Mak R, Van Maele G, Kornitzer M, De Backer G. Job stress among middle-aged health care workers and its relation to sickness absence. Stress Health 2003;19:26574.

7. Chan KB, Lai G, Ko YC, Boey KW. Work stress among six professional groups: the Singapore experience. Soc Sci Med 2000;50:1415-32.

8. McVicar A. Workplace stress in nursing: a literature review. J Adv Nurs 2003;44:633-42.

9. Smith A, Brice C, Collins A, Matthews V, McNamara R. The scale of occupational stress: a further analysis of the impact of demographic factors and type of job. HSE Contract Research Report 311/2000. Suffolk: Health and Safety Executive; 2000.

10. Stacciarini JMR, Tróccoli BT. Occupational stress and constructive thinking: health and job satisfaction. J Adv Nurs 2004:46:480-7.

11. Feskanich D, Hastrup JL, Marshall JR, Colditz GA, Stampfer MJ, Willett WC, Kawachi 1. Stress and suicide in the Nurses' Health Study. J Epidemiol Commun Health 2002;56:95-8.

12. Kawano Y. Association of job-related stress factors with psychological and somatic symptoms among Japanese hospital nurses: effect of departmental environment in acute care hospitals. J Occup Health 2008;50:79-85.

13. Nedić O, Filipović D, Šolak Z. Job stress and cardiovascular diseases with health workers. Med Pregl 2001;54:423-31. 
14. Gonge H, Jensen LD, Bonde JP. Are psychosocial factors associated with low-back pain among nursing personnel? Work Stress 2002;16:79-87.

15. Piko B. Psychosocial work environment and psychosomatic health of nurses in Hungary. Work Stress 2003;17:93-100.

16. Gray-Toft P, Anderson JG. The nursing stress scale: development of an instrument. J Psychopathol Behav Assess 1981;3:11-23.

17. Gray-Toft P, Anderson JG. Stress among hospital nursing staff: Its causes and effects. Soc Sci Med A 1981;15:63947.

18. Golubic R, Milosevic M, Knezevic B, Mustajbegovic J. Work-related stress, education and work ability among hospital nurses. J Adv Nurs 2009;65:2056-66.

19. Hall DS. Work-related stress of registered nurses in a hospital setting. J Nurses Staff Dev 2004;20:6-14.

20. Hamaideh SH, Mrayyan MT, Mudallal R, Faouri IG, Khasawneh NA. Jordanian nurses' job stressors and social support. Int Nurs Rev 2008;55:40-7.

21. Healy C, McKay M. Identifying sources of stress and job satisfaction in the nursing environment. Aust J Adv Nurs 1999;17:30-5.

22. Hipwell AE, Tyler PA, Wilson CM. Sources of stress and dissatisfaction among nurses in four hospital environments. Br J Med Psychol 1989;62:71-9.

23. Mäkinen A, Kivimäki M, Elovainio M, Virtanen M Organization of nursing care and stressful work characteristics. J Adv Nurs 2003;43:197-205.

24. Foxall M, Zimmerman L, Standley R, Captain BB. A comparison of frequency and source of nursing job stress perceived by intensive care, hospice and medical-surgical nurses. J Adv Nurs 1990;15:577-84.

25. Milutinović D, Grujić N, Jocić N. Identifikacija i analiza stresogenih faktora na radnom mestu medicinskih sestara komparativna studija četiri klinička odeljenja [Identification and analysis of stress factors at nursing workplace. A comparative study of four clinical departments, in Serbian]. Med Pregl 2009;62:68-73.

26. Mrayyan MT. Job stressors and social support behaviors: comparing intensive care units to wards in Jordan. Contemp Nurse 2009;31:163-75.
27. Cavalheiro AM, Moura Junior DF, Lopes AC. Stress in nurses working in intensive care units. Rev Lat Am Enfermagem 2008;16:29-35.

28. French SE, Lenton R, Walters V, Eyles J. An empirical evaluation of on expanded Nursing Stress Scale. J Nurs Meas 2000;8:161-78.

29. Cha E-S, Kim KH, Erlen, JA. Translation of scales in crosscultural research: issues and techniques. J Adv Nurs 2007;58:386-95.

30. Galanakis M, Stalikas A, Kallia H, Karagianni C, Karela C. Gender differences in experiencing occupational stress: the role of age, education and marital status. Stress Health 2009:25:397-404

31. Escot C, Artero S, Gandubert C, Boulenger JP, Ritchie K. Stress levels in nursing staff working in oncology. Stress Health $2001 ; 17: 273-9$.

32. Lin K-C, Huang C-C, Wu C-C. Association between stress at work and primary headache among nursing staff in Taiwan. Headache 2007;47:576-84.

33. Yip YB. The association between psychosocial work factors and future low back pain among nurses in Hong Kong: a prospective study. Psychol Health Med 2002;7:223-33.

34. Portela LF, Rotenberg L, Waissmann W. Self-reported health and sleep complaints among nursing personnel working under 12h night and day shifts. Chronobiol Int 2004;21:859-70.

35. Paulsson $\mathrm{K}$, Ivergård $\mathrm{T}$, Hunt $\mathrm{B}$. Learning at work: competence development or competence-stress. Appl Ergon 2005;36:135-44.

36. Arnetz BB, Wiholm C. Technological stress: psychophysiological symptoms in modern offices. J Psychosom Res 1997;43:35-42.

37. Heraclides A, Chandola T, Witte DR, Brunner EJ. Psychosocial stress at work doubles the risk of type 2 diabetes in middle-aged women: evidence from the Whitehall II study. Diabetes Care 2009;32:2230-5.

38. Pukkala E, Härmä M. Does shift work cause cancer? Scand J Work Environ Health 2007;33:321-3.

39. McNeely E. The consequences of job stress for nurses' health: time for a check-up. Nurs Outlook 2005;53:291-9. 


\section{Sažetak}

\section{STRES NA RADU I ZDRAVLJE MEDICINSKIH SESTARA U JEDINICAMA INTENZIVNE NJEGE} U SRBIJI

Cilj je ovoga rada bio identificirati i analizirati profesionalne stresore, procijeniti razinu stresa kod medicinskih sestara u jedinicama intenzivne njege te procijeniti korelaciju između percepcije stresa $\mathrm{i}$ prisutnosti psiholoških i somatskih simptoma ili bolesti kod medicinskih sestara. Istraživanje je provedeno u obliku studije presjeka u Jedinicama intenzivne njege u zdravstvenim centrima u Srbiji. Uzorak se sastojao od 1000 medicinskih sestara-tehničara. Za procjenu i analizu profesionalnih stresora korišten je upitnik Expanded Nursing Stress Scale (ENSS), koji je pokazao validne metrijske karakteristike na našoj ispitanoj populaciji. Medicinske sestre u Jedinicama intenzivne njege ocijenile su situacije iz fizičkoga i psihološkoga radnog okruženja kao izrazito opterećujuće, a situacije iz socijalnoga radnog okruženja kao manje opterećujuće. Razlika u percepciji stresogenosti navedenih radnih okruženja nije bila statistički značajna. Sociodemografske determinante ispitanika (dob, bračno stanje i stupanj obrazovanja) značajno utječu na percepciju stresa na radnom mjestu. Utvrđena je statistički značajna razlika u opažanju stresogenosti pojedinih stresnih situacija na radnom mjestu između medicinskih sestara u odnosu na postojanje psihosomatskih simptoma (kao što su glavobolja, nesanica, umor, očaj, bol u leđima, česte promjene raspoloženja) ili određenih bolesti (kao što su povišena hipertenzija, infarkt miokarda, cerebrovaskularni inzult, šećerna bolest). Zbog sve izraženije prisutnosti profesionalnih stresora nužno je poduzeti određene strateške mjere kod medicinskih sestara u Jedinicama intenzivne njege. Strateške mjere podrazumijevaju unaprjeđenje psihosocijalne radne klime, što bi unaprijedilo njihovo zdravlje i spriječilo nastanak bolesti u svezi s radom, ali i omogućilo bolju zaštitu već oboljelim medicinskim sestrama.

KLJUČNE RIJEČI: profesionalni stresori, psihološki i somatski simptomi, radno mjesto, radno opterećenje, upitnici

\section{CORRESPONDING AUTHOR:}

Dragana Milutinović, PhD, RN

Faculty of Medicine, Department of Nursing

Hajduk Veljkova 3, 21000 Novi Sad, Serbia

E-mail: milutind@uns.ac.rs; milutind021@gmail.com 